\title{
MEIO SÉCULO DE INOVAÇÕES NA EAESP-FGV
}

\section{HÁ MAIS DE CINQUENTA ANOS, A EAESP-FGV É MUNDIALMENTE CONHECIDA POR SEU PIONEIRISMO E TRANSFORMAÇÕES POSITIVAS NO ENSINO E RECONHECIMENTO DA ADMINISTRAÇÃO COMO PROFISSÃO}

CLAUDE MACHLINE, professor emérito da FGV-EAESP, claude.machline@fgv.br

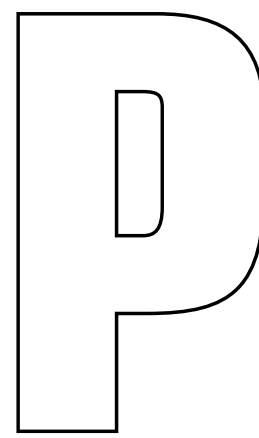
assado pouco mais de meio século do início do ensino de administração de empresas e da formação de administradores profissionais no País, torna-se oportuno resgatar as tantas inovações criadas na Escola de Administração de Empresas de São Paulo da

Fundação Getulio Vargas, a EAESP-FGV.

Foram inovações institucionais, estruturais, administrativo-financeiras, acadêmicas e educacionais que, apesar do tempo em que ocorreram, ainda nos trazem orientações úteis para um mundo no qual, sem inovações, não sobrevive a empresa.

INOVAÇÕES INSTITUCIONAIS. A primeira inovação foi a própria criação da EAESP, que fugiu totalmente do padrão de criação das instituições de ensino superior na época. Participaram dessa gênese, em 1954, não somente a Fundação Getulio Vargas, mas o Ministério da Educação e Cultura, a Capes, a Federação das Indústrias do Estado de São Paulo, o Instituto de Organização Racional do Trabalho (Idort), o Departamento de Relações Exteriores dos Estados Unidos, a Embaixada Norte-
Americana no Brasil, a Usaid - uma agência do Governo norte-americano, a Fundação Ford, que aportou recursos significativos, assim como outras instituições e empresas nacionais e estrangeiras.

O próprio Presidente da República assim se pronunciou, em 1952, em apoio à iniciativa:

"A criação da Escola de Administração Pública, no Rio de Janeiro, pela Fundação Getulio Vargas, estabeleceu no Brasil o ensino sistemático dos métodos e técnicas de trabalho aplicados aos negócios públicos. A Escola Universitária de Administração de Empresas que a Fundação Getulio Vargas quer estabelecer em São Paulo será também um vigoroso reforço para instituir o ensino da administração, que o Brasil tanto necessita". (Discurso do Presidente Getulio Vargas citado no livro Institution building: the Brazilian experience, do autor Donald Taylor).

No início, o Governo norte-americano designou uma missão de professores da Michigan State University, que permaneceu em São Paulo por mais de 10 anos, ministrando aulas, orientando alunos, estabelecendo contatos com a comunidade de ne- 


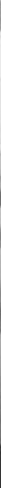

Reunião de alunos do curso de Administração; banca de professores; professores americanos na EAESP

de Administração, formado por personalidades do mundo empresarial, algo original no meio acadêmico. Os alunos do curso de graduação, dotados de singular criatividade, formaram um Diretório Acadêmico extremamente ativo, que teve muitas de suas reivindicações pedagógicas atendidas, tais como avaliação dos professores pelos alunos e oferta regular de disciplinas optativas, algo incomum na década de 1960.

Comum nos EUA, mas novidade no Brasil, foi a criação de uma Associação de Ex-Alunos, com representação no Conselho de Administração e participante do dia a dia da Escola. A criação, em 1988, da primeira Empresa Júnior da América Latina foi também um marco da criatividade do alunado da EAESP.

\section{INOVAÇÕES ADMINISTRATIVO-}

FINANCEIRAS. A criação, em 1965, do Fundo Rotativo de Bolsa, ou Bolsa Reembolsável, foi outra inovação do curso de graduação para apoiar alunos sem condições de pagar as mensalidades. Constituído por doações efetuadas por empresas e ex-alunos, o Fundo conta hoje com algumas dezenas de milhões de reais e foi estendido aos alunos de pós-graduação.

O modelo de parceria com numerosas empresas - são, hoje, mais de 150 parceiros - foi outra inovação relevante. Ao contribuir financeiramente com a Escola, a empresa investe na melhoria de sua infraestrutura, patrocina uma pesquisa do seu interesse ou o desenvolvimento de um programa didático especial, além de ter retorno de imagem. Uma doação da Petrobras, por exemplo, permitiu montar a primeira instalação de Educação a Distância (EAD) no Brasil, em 1990.

A carreira do professor sofreu total alteração em relação à carreira tradicional das faculdades nacionais. Já era consenso na época que o sistema vigente, constituído por um professor catedrático, dono perpétuo de sua cátedra e senhor de sua dis- ciplina, auxiliado por instrutores de ascensão problemática, era sufocante e teria que ser alterado. No plano de carreira implantado, todos os professores ingressam por concurso, progridem por mérito e tempo, passando sucessivamente a instrutores, auxiliares de ensino, adjuntos e titulares. Muitas faculdades e universidades adotaram modelo semelhante após a inovação ser lançada pela EAESP.

INOVAÇÕES ACADÊMICAS. Em plena década de 1950, pensar a administração de empresas no nível universitário como uma nova profissão em pé de igualdade com as mais tradicionais e respeitadas profissões, como direito, medicina, engenharia, contabilidade, economia, era, no mínimo, um absurdo. Mesmo nos Estados Unidos, o pensamento dominante era que o estudo de administração fosse efetuado em nível de pós-graduação lato sensu, para profissionais já formados em cursos tradicionais e que tivessem alguns anos de prática em cargos gerenciais. Na mesma época, na Europa, havia cursos famosos de graduação em escolas comerciais e de economia, mas não propriamente de administração. Nesse sentido, a criação do curso de graduação em administração de empresas pela EAESP constituiu, como conseqüência, uma nova carreira profissional.

À medida que novas ferramentas de administração iam sendo desenvolvidas em outros países, a EAESP-FGV, em 1955, por meio de seus contatos internacionais e convênios com instituições no exterior, era das primeiras a divulgá-las, sempre se mantendo na vanguarda do conhecimento atualizado, mas também procurando resguardar as empresas contra modismos passageiros e falsas panaceias.

A EAESP também lançou a mais antiga revista acadêmica de administração de empresas do país em 1961, a RAE, e já nos anos 2000 criou outra 
